\title{
Knowledge, attitude and practice of long acting reversible hormonal contraception (LARHC) among women in urban upper Egypt
}

\author{
Abo bakr A. Mitwaly ${ }^{1}$, Ahmed M. Abbas ${ }^{1 *}$, Amal Fathy Mohammed², Alaa M. Ismail', \\ Ayman H. Shaamash ${ }^{1}$, Alaa El Din A. Youssef ${ }^{1}$
}

\begin{abstract}
${ }^{1}$ Department of Obstetrics and Gynecology, Faculty of Medicine, Assiut University, Assiut, Egypt
${ }^{2}$ Department of Obstetrics and Gynecology, Gehina Central Hospital, Sohag, Egypt
\end{abstract}

Received: 31 January 2019

Accepted: 06 March 2019

\section{*Correspondence:}

Dr. Ahmed M. Abbas,

E-mail: bmr90@hotmail.com

Copyright: () the author(s), publisher and licensee Medip Academy. This is an open-access article distributed under the terms of the Creative Commons Attribution Non-Commercial License, which permits unrestricted non-commercial use, distribution, and reproduction in any medium, provided the original work is properly cited.

\begin{abstract}
Background: The current study aims to assess the knowledge, attitude and practice of long acting reversible hormonal contraception (LARHC) among women in urban upper Egypt.

Methods: A cross sectional study which included 902 married women, in the reproductive age, attending the outpatient clinics (Gynecology and family planning) of: 1-Assiut University Maternity Hospital, 2- Sohag University Hospital, and 3-Gehina General Hospital (MOH hospital) with current or previous use of any method of LARHC methods. A Questionnaire file was designed to assay knowledge attitude and practice of clients towards contraceptive methods. All data collected from clients reviewed separately to assess knowledge, attitude and practice of women towards contraceptive methods.

Results: The most popular contraceptive method is COCs followed by IUD then DMPA. 99\% of studied sample heard with good description about different types of LARHC. 54.9\% of studied sample most popular/famous LARHC DMPA, most sources of information on LARHC were, Hospital, Relative/friends and health workers. $94.24 \%$ of the studied sample were in favor to use of LARHC, $94.2 \%$ of them agree to take a space between births, about $55.4 \%$ of them were health child and $61 \%$ comfortable lifestyle benefit from birth spacing, $33 \%$ of studied sample were maternal health, $68 \%$ of them were think/prefer to use implants, $64.5 \%$ of them didn't pregnant while breastfeeding. $11 \%$ of sample women never used any contraception before and most reasons for not using contraception are fear of side effects, desire for more children, irregular sexual relationship, and husband opposition. Only $16.6 \%$ of studied sample used LARHC before and most of them used DMPA, however 3 women who used DMPA get pregnant while using it.
\end{abstract}

Conclusions: There is a good level of knowledge between upper Egypt women about LARHC methods.

Keywords: Attitude, Implants, Knowledge, LARC, Practice

\section{INTRODUCTION}

A KAP survey is conducted to investigate human behavior related to a certain topic. It identifies what people know (Knowledge), how they feel (Attitude), and what they do (Practice). KAP studies can be used for diagnostic purposes for which they describe the population's current knowledge, attitude and practice.

Secondly, they can be implemented to increase insights in a current situation and help design appropriate specific interventions. Thirdly, they can be used as an evaluation 
tool to evaluate the effectiveness of certain interventions or programs. ${ }^{1}$

The KAP survey was developed in the 50's and was originally designed to research family planning in the Third World. These sample surveys were very popular during the fifties and sixties: several hundred KAP studies were carried out in several dozen countries. ${ }^{2}$

Developing countries have a high birth rate and a high total fertility rate relative to those of developed countries; however, the last few years have shown a marked drop in both rates. ${ }^{3}$ The use of contraceptives has been recognized as a key element in reducing fertility for all age groups in many developing countries. ${ }^{4}$

Review of literature shows that the advantages of proper child spacing are enormous, as a high fertility rate has been linked with underdevelopment in developing countries. ${ }^{5}$ Birth spacing has been identified by the World Health Organization as one of the six essential health interventions needed to achieve safe motherhood. ${ }^{6}$

Because long-acting reversible contraception (LARC) methods have very high efficacy and low burden to users after their initiation, the American College of Obstetricians and Gynecologists (ACOG) recommends that women be offered LARC as first-line contraceptive methods. $^{7}$ These methods, which include intrauterine devices (IUD) or systems (IUS) and contraceptive implants, avoid the need for frequent visits for resupply, are highly cost effective, and allow a rapid return to fertility after their removal. ${ }^{8}$

However, according to NICE guidelines LARC is defined in this guideline as contraceptive methods that require administration less than once per cycle or month. Included in the category of LARC are copper intrauterine devices progestogen-only intrauterine systems, progestogen-only injectable contraceptives and progestogen-only subdermal implants. ${ }^{9}$

Several KAP surveys, with different objectives, had been carried out in Egypt to evaluate family planning methods, programs and certain interventions. However, far to our knowledge, no similar KAP surveys were carried out to investigate the Knowledge, attitude, and practice of Long Acting Reversible Hormonal Contraception (LARHC) among Egyptian women.

This study aimed to answer the following questions: What is the knowledge do women have about LAHRC (DMPA, Implants and, hormonal IUS) methods in Urban Upper Egypt region. What are their attitudes (their opinion, feelings and thoughts about contraceptive methods, prefer to use or not) towards different contraceptives. What is the practice (currently use, discontinuation or switching) of different LAHRC methods.

\section{METHODS}

This study is a cross sectional study which included 902 married women, in the reproductive age, attending the outpatient clinics (Gynecology and family planning) of: 1-Assiut University Maternity Hospital, 2- Sohag University Hospital, and 3-Gehina General Hospital (MOH hospital) with current or previous use of any method of LARHC methods.

\section{Inclusion criteria}

- Women aged from 18-49 who has one child or more and used contraceptive method once or more were included. These clients either continued or discontinued the method later on.

Sample size was calculated on the assumption that the rate of women aged 18-45 years to the total population was $22.3 \%$, considering a degree of precision 0.05 , a design effect 1.8 and non- response rate $30 \%$. A sample size of 902 married women was decided upon. The sample size was distributed with proportional among different centers. A questionnaire file was designed to assay knowledge attitude and practice of clients towards contraceptive methods.

All data collected from clients reviewed separately to assess knowledge, attitude and practice of women towards contraceptive methods. These data involved level of knowledge of women about different contraceptive methods in general and source of information, attitude of women towards long acting reversible hormonal contraceptive methods and history of contraception use and what hormonal methods used before and if it discontinued, switched, or failed. Analysis of percentage of using of long acting hormonal contraceptive methods. Analysis of percentage of discontinuation, switching, failure of long acting hormonal contraceptive methods. Analysis of percentage of side effects or complications of long acting reversible hormonal contraceptive methods.

Data collection methods: Framing the questionnaire file has taken a lot of time to adapt the social, demographic characteristics of our community and hormonal methods available now in different family planning sectors.

Questions are closed type including variable choices of level of knowledge about different types of contraceptive methods in general and practice of women of hormonal methods, from these data authors calculate of percentage of using, discontinuation, switching and failure of long acting hormonal contraceptive methods.

\section{Statistical analysis}

Data entry and data analysis were done using SPSS version 21 (Statistical Package for Social Science). Data were presented as mean and standard deviation. Chisquare and Fisher Exact tests were used to compare 
between qualitative variables. Independent samples t-test was used to compare between two quantitative variables. $\mathrm{P}$-value considered statistically significant when $\mathrm{P}<0.05$.

\section{RESULTS}

Table 1 shows that $60 \%$ of the studied sample from Sohag clinic, about $50 \%$ of them their age ranged from 26 to 35 years with mean $31.1 \pm 9.4$. Secondary were the most education level with $46.4 \%$. Housewife occupation were in $37.1 \%$, About $71 \%$ of them had parity from $2-4$ times, most of them $(63.9 \%)$ their husband age ranged from $36-40$ years and $45.4 \%$ of them were secondary educated.

Table 1: Socio-demographic data of the study participants.

\begin{tabular}{|c|c|c|}
\hline & No. & $\%$ \\
\hline \multicolumn{3}{|l|}{ Clinic } \\
\hline Assiut & 360 & 39.9 \\
\hline Sohag & 542 & 60.1 \\
\hline \multicolumn{3}{|l|}{ Age groups } \\
\hline $15-25$ years & 137 & 15.2 \\
\hline $26-35$ years & 455 & 50.4 \\
\hline $36-40$ years & 210 & 23.3 \\
\hline$>40$ years & 100 & 11.1 \\
\hline Mean \pm SD & \multicolumn{2}{|l|}{$33.3 \pm 8.2$} \\
\hline \multicolumn{3}{|l|}{ Level of education } \\
\hline Illiterate & 100 & 11.1 \\
\hline Primary & 70 & 7.8 \\
\hline Secondary & 400 & 44.3 \\
\hline University & 312 & 34.6 \\
\hline Postgraduate & 20 & 2.2 \\
\hline \multicolumn{3}{|l|}{ Occupation } \\
\hline Housewife & 102 & 11.3 \\
\hline Nurse & 200 & 22.2 \\
\hline Teacher & 200 & 22.2 \\
\hline Employee & 300 & 33.3 \\
\hline Local work & 100 & 11.0 \\
\hline \multicolumn{3}{|l|}{ Parity } \\
\hline 1 & 110 & 12.2 \\
\hline $2-4$ & 600 & 66.5 \\
\hline 5 or more & 192 & 21.3 \\
\hline Mean \pm SD & $3.2 \pm 1.5$ & \\
\hline \multicolumn{3}{|l|}{ Husbands age } \\
\hline $15-25$ years & 150 & 16.6 \\
\hline $26-35$ years & 302 & 33.5 \\
\hline $36-40$ years & 400 & 44.3 \\
\hline$>40$ years & 50 & 5.5 \\
\hline Mean \pm SD & \multicolumn{2}{|l|}{$37.7 \pm 12.1$} \\
\hline \multicolumn{3}{|l|}{ Husbands education } \\
\hline Illiterate & 100 & 11.1 \\
\hline Primary & 192 & 21.3 \\
\hline Secondary & 300 & 33.3 \\
\hline University & 290 & 32.2 \\
\hline Postgraduate & 20 & 2.2 \\
\hline
\end{tabular}

Table 2 shows that the most popular contraceptive method is COCs followed by IUD and followed by DMPA. $99 \%$ of studied sample heard with good description about different types of LARHC. $54.9 \%$ of studied sample most popular/famous LARHC DMPA, most sources of information on LARHC were, hospital, relative/friends and health workers.

Table 2: Knowledge of family planning methods and LARHC.

\begin{tabular}{|c|c|c|}
\hline & No. & $\%$ \\
\hline \multicolumn{3}{|c|}{ Most popular contraceptive method in general } \\
\hline $\mathrm{COCs}$ & 300 & 33 \\
\hline DMPA & 150 & 17 \\
\hline Breastfeeding & 100 & 11 \\
\hline POPs & 50 & 5.5 \\
\hline Condom & 10 & 1 \\
\hline Safe period & 5 & 0.5 \\
\hline IUDs & 200 & 22 \\
\hline Tubal ligation & 10 & 1 \\
\hline Withdrawal & 2 & .2 \\
\hline Implants & 70 & 8 \\
\hline Mirena & 5 & .5 \\
\hline Sterlization & 0 & 0 \\
\hline \multicolumn{3}{|c|}{ Level of knowledge about different types of LARHC } \\
\hline No knowledge & 0 & 0.0 \\
\hline Heard with good description & 852 & 94.5 \\
\hline Heard with poor description & 50 & 5.5 \\
\hline \multicolumn{3}{|c|}{ Most popular/famous LARHC in your opinion } \\
\hline Implants & 352 & 39.0 \\
\hline Mirena & 0 & 0.0 \\
\hline DMPA & 550 & 61.0 \\
\hline \multicolumn{3}{|c|}{ Source of information on LARHCs } \\
\hline TV/Radio & 0 & 0.0 \\
\hline Mother & 300 & 33.3 \\
\hline Husband & 3 & 0.3 \\
\hline Hospital & 300 & 33.3 \\
\hline Relative/friends & 200 & 22.2 \\
\hline Private doctor & 300 & 33.3 \\
\hline Health workers & 770 & 85.4 \\
\hline Others & 0 & 0.0 \\
\hline
\end{tabular}

Table 3 shows that $94.24 \%$ of the studied sample were in favor to use of LARHC, $94.2 \%$ of them agree to take a space between births, about $55.4 \%$ of them were health child and $61 \%$ comfortable lifestyle benefit from birth spacing, $33 \%$ of studied sample were maternal health, $68 \%$ of them were think/prefer to use implants, $64.5 \%$ of them didn't pregnant while breastfeeding.

Table $4 \mathrm{a}$ and $4 \mathrm{~b}$ showed that $11 \%$ of sample women never used any contraception before and most reasons for not using contraception are fear of side effects, desire for more children, irregular sexual relationship, and husband opposition. About only $16.6 \%$ of studied sample used LARHC before and most of them used DMPA, however 3 women who used DMPA get pregnant while using it. 
About $88.7 \%$ of studied sample women were not using LARHC now. The most common reason for using LARHC by the rest of studied sample is child spacing or fertility termination. About $83.3 \%$ of women who used LARHC have side effects most common is menstrual irregularities and weight gain, and about $58.8 \%$ of them decide to remove LARHC method for side effects. Most of the studied sample women were counseled by a doctor.

Table 3: Attitude towards family planning methods and LARHC.

\begin{tabular}{|c|c|c|}
\hline & No. & $\%$ \\
\hline \multicolumn{3}{|c|}{ Attitude towards the use of LARHC } \\
\hline In favor & 850 & 94.2 \\
\hline Not in favor & 52 & 5.8 \\
\hline \multicolumn{3}{|c|}{ Do you agree to take a space between births } \\
\hline Yes & 850 & 94.2 \\
\hline No & 52 & 5.8 \\
\hline \multicolumn{3}{|c|}{ If yes what is the suggested interval } \\
\hline 1 year & 50 & 5.5 \\
\hline 2 years & 170 & 18.8 \\
\hline 3 years & 500 & 55.4 \\
\hline 4 years & 150 & 16.6 \\
\hline 5 years & 32 & 3.5 \\
\hline \multicolumn{3}{|l|}{ Benefit from birth spacing } \\
\hline Better health for the mother & 300 & 33.3 \\
\hline Healthy child & 500 & 55.4 \\
\hline Comfortable lifestyle & 550 & 61.0 \\
\hline Others (like husband travel) & 220 & 24.4 \\
\hline \multicolumn{3}{|c|}{$\begin{array}{l}\text { Factor influencing your attitude and practice on } \\
\text { LARHC }\end{array}$} \\
\hline Religious reason & 400 & 44.3 \\
\hline Maternal health & 100 & 11.1 \\
\hline Husband's influence & 100 & 11.1 \\
\hline Cost & 5 & 0.6 \\
\hline Fear of infertility & 294 & 32.6 \\
\hline Other & 3 & 0.3 \\
\hline \multicolumn{3}{|c|}{ Which LARHC method do you think/prefer to use } \\
\hline Mirena & 5 & 0.50 \\
\hline Implants & 615 & 68 \\
\hline DMPA & 282 & 31 \\
\hline \multicolumn{3}{|c|}{ Did you get pregnant while breastfeeding } \\
\hline Yes & 320 & 35.5 \\
\hline No & 582 & 64.5 \\
\hline
\end{tabular}

Table 5 presents the significant predictors of knowledge level about family planning methods. Occupation and average monthly income were the most significant predictors $(\mathrm{p}=0.001)$.

Table 6 presents the significant predictors of attitude toward family planning methods. Age group, educational level, occupation and years of marriage were the most significant predictors.

Table 7 presents the significant predictors of practice of family planning methods. Educational level, parity, nature of marriage and years of marriage were the most significant predictors.

Table 4a: Practice of family planning methods and LARHC.

\begin{tabular}{|c|c|c|}
\hline & No. & $\%$ \\
\hline \multicolumn{3}{|l|}{ Have you ever used a contraceptive } \\
\hline Yes & 802 & 89 \\
\hline No & 100 & 11 \\
\hline \multicolumn{3}{|c|}{$\begin{array}{l}\text { If no what is your reason for not using any } \\
\text { contraceptive }(n=100)\end{array}$} \\
\hline It is expensive & 0 & 0.0 \\
\hline Medical reason & 5 & 5 \\
\hline Husband's opposition & 10 & 10 \\
\hline Prohibited & 0 & 0.0 \\
\hline Religion & 18 & 1.8 \\
\hline Ashamed to buy & 0 & 0.0 \\
\hline Irregular sexual relation & 13 & 1.3 \\
\hline Lack of information on how to use it & 5 & 0.05 \\
\hline Desire for more children & 25 & 2.5 \\
\hline Lack of knowledge of where to get it & 0 & 0.0 \\
\hline Fear of side effects & 24 & 2.4 \\
\hline \multicolumn{3}{|c|}{ Have you ever used any LARHC method } \\
\hline Yes & 150 & 16.6 \\
\hline No & 752 & 83.4 \\
\hline \multicolumn{3}{|c|}{ If yes what method of LARHC did you use } \\
\hline Implants & 30 & 20.0 \\
\hline Mirena & 0 & 0.0 \\
\hline DMPA & 120 & 80.0 \\
\hline
\end{tabular}

Where did you go to obtain your LARHC method

\begin{tabular}{|l|l|l|}
\hline Referral hospital & 100 & 66.7 \\
\hline Health center & 20 & 13.3 \\
\hline Private doctor & 30 & 20.0 \\
\hline
\end{tabular}

Did you get pregnant while using any LARHC methods before

\begin{tabular}{|l|l|l|}
\hline Yes & 5 & 3.33 \\
\hline No & 145 & 96.6 \\
\hline
\end{tabular}

If yes what is your failed LARHC method

\begin{tabular}{|l|l|l|}
\hline Implants & 2 & 40 \\
\hline Mirena & 0 & 0.0 \\
\hline DMPA & 3 & 60 \\
\hline Do you use any LARHC method currently & \\
\hline No & 752 & 83.3 \\
\hline Implants & 50 & 5.5 \\
\hline Mirena & 0 & 0.0 \\
\hline DMPA & 100 & 11 \\
\hline
\end{tabular}

Primary reason for current LARHC use $(\mathbf{n}=150)$

\begin{tabular}{|l|l|l|} 
For fertility termination & 80 & 53
\end{tabular}

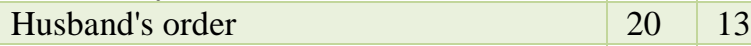

\begin{tabular}{|l|l|l|}
\hline Spacing of births & 30 & 20
\end{tabular}

\begin{tabular}{l|l|l} 
Due to medical disorder & 20 & 13
\end{tabular}

Do you have side effects from your current

LARHC method $(\mathbf{n}=150)$

\begin{tabular}{|l|l|l|}
\hline Yes & 120 & 80 \\
\hline No & 30 & 20 \\
\hline
\end{tabular}


Table 4b: Practice of family planning methods and LARHC.

\begin{tabular}{|c|c|c|}
\hline & $\mathbf{N}$ & $\%$ \\
\hline \multicolumn{3}{|l|}{ If yes $(n=120)$} \\
\hline Menstrual disturbance & 50 & 41 \\
\hline Skin patches & 3 & 2.5 \\
\hline Weight gain & 12 & 10 \\
\hline Difficult to regain fertility & 20 & 17 \\
\hline Backache & 10 & 8 \\
\hline Headache & 10 & 8 \\
\hline Nervousness & 10 & 11.8 \\
\hline Nausea & 0 & 0.0 \\
\hline Infection & 5 & 4 \\
\hline \multicolumn{3}{|c|}{$\begin{array}{l}\text { Do you plan to remove your LARHC method for } \\
\text { the side effects }(n=120)\end{array}$} \\
\hline Yes & 70 & 58 \\
\hline No & 50 & 42 \\
\hline \multicolumn{3}{|c|}{ Who did counsel you $(n=150)$} \\
\hline Doctor & 100 & 67 \\
\hline Nurse & 50 & 33 \\
\hline Mother & 0 & 0.0 \\
\hline
\end{tabular}

Table 5: Multiple regression analysis to assess the significant predictors of knowledge level about family planning methods and LARHCs.

\begin{tabular}{|l|l|l|}
\hline Age group & -1.21 & 0.318 \\
\hline $\begin{array}{l}\text { Level of education } \\
\text { (high education) }\end{array}$ & 2.03 & $0.037^{*}$ \\
\hline Occupation (employed) & 2.67 & $0.001^{* *}$ \\
\hline Parity & 1.16 & 0.241 \\
\hline Husbands age & 0.69 & 0.477 \\
\hline Husbands education & 0.73 & 0.319 \\
\hline Nature of marriage & -1.27 & 0.167 \\
\hline Average monthly income & 2.79 & $0.001^{* *}$ \\
\hline Years of marriage & 2.01 & $0.046^{*}$ \\
\hline
\end{tabular}

* Statistically significant predictors $(\mathrm{p}<0.05)$

** Statistically significant predictors $(\mathrm{p}<0.01)$

Table 6: Multiple regression analysis to assess the significant predictors of attitude toward family planning and LARHCs.

\begin{tabular}{|l|l|l|}
\hline Age group & $\mathrm{t}$ & Sig. \\
\hline $\begin{array}{l}\text { Level of education } \\
\text { (high education) }\end{array}$ & -2.71 & $0.001^{* *}$ \\
\hline Occupation (employed) & 2.58 & $0.001^{* *}$ \\
\hline Parity & -0.54 & $0.010^{* *}$ \\
\hline Husbands age & 1.27 & 0.591 \\
\hline Husbands education & -0.41 & 0.224 \\
\hline Nature of marriage & 1.91 & 0.061 \\
\hline Average monthly income & 1.80 & 0.069 \\
\hline Years of marriage & 2.64 & $0.008^{* *}$ \\
\hline * Statistically significant predictors $(\mathrm{p}<0.05)$ & \\
\hline$* *$ Statistically significant predictors $(\mathrm{p}<0.01)$ & \\
\hline
\end{tabular}

Table 7: Multiple regression analysis to assess the significant predictors of practice of family planning and LARHCs.

\begin{tabular}{|l|l|l|}
\hline & $\mathrm{t}$ & Sig. \\
\hline Age group & 0.40 & 0.671 \\
\hline Level of education & 2.84 & $0.001^{* *}$ \\
\hline Occupation & 2.11 & $0.032^{*}$ \\
\hline Parity & 8.74 & $0.001^{* *}$ \\
\hline Husbands age & 1.55 & 0.474 \\
\hline Husbands education & 2.33 & $0.017 *$ \\
\hline Nature of marriage & -5.62 & $0.009^{* *}$ \\
\hline Average monthly income & 1.02 & 0.331 \\
\hline Years of marriage & 3.92 & $0.001 * *$ \\
\hline * Statistically significant predictors $(\mathrm{p}<0.05)$ \\
** Statistically significant predictors $(\mathrm{p}<0.01)$ \\
\hline
\end{tabular}

\section{DISCUSSION}

There are multiple studies were done in many countries all over the world to asses level of knowledge, attitude, and practice of women towards contraceptive methods. Good knowledge and positive attitudes towards an intervention or a new practice by a target group are among the key determinants for adoption.

As regard knowledge, in a study done in Jordan revealed that women in rural areas of the southern region of Jordan had incomplete knowledge about the concept of family planning and some women $(8.7 \%)$ stated that they did not know what family planning referred to and this not agreed with present study. In present study knowledge about contraception between women is high as all women in present study know about contraceptive methods.

Similar view among study participants was also noted in a study by Mengistu et al, in Ethiopia. Main source of information on modern contraceptives were government health facilities such as hospitals and dispensaries. The following quote from one participants of Focus Group Discussions (FGDs) support this observation; "Every time we go at the hospital or dispensary first before being attended we are given a seminar on the importance of modern family planning methods and how to use them". ${ }^{10}$ This observation demonstrates good efforts made by the government in promoting modern contraceptives even in rural areas, a practice which is commendable.

Also, regarding knowledge in another study had been done in Tafila city in Jordan and knowledge related to contraceptive methods results showed that 560 (93.3\%) of the currently married women recognized at least one method of family planning, $412(69.5 \%)$ knew two methods, and only $260(43.3 \%)$ knew three or more methods. IUCD was the most frequently mentioned method $(85 \%)$ followed by coitus interruption $(51.4 \%)$ and oral contraceptive pills (OCP) $(46.5 \%)$, safe period (45.3\%), sterilization (43.3\%) and condom 219 (36.5\%). The least mentioned method was injection 141 (23.5\%). 
As regard attitude In a study done In Jordan it was that women in rural areas of the southern region of Jordan had 97.3\% agreed to postpone pregnancy for better health to child, also $97.3 \%$ of women have to 2-year spacing between pregnancies, and $90.8 \%$ of women had to use family planning methods to prevent pregnancy, $78.9 \%$ of women think they should use family planning methods just after delivery to prevent unwanted pregnancy, also $63.6 \%$ think that women should start using family planning methods immediately after first child. And this agreed with present study. as in present study $94.2 \%$ had positive attitude toward use contraceptive methods especially LARHC and agreed to take a space between births $55.4 \%$ of them suggested that 3 years is a good interval.

As regard attitude the study done in Jordan revealed that the results indicate a good number of study participants had positive attitude towards modern contraceptives. Results show that half $(50 \%)$ of total respondents that were aware of modern contraceptives thought that benefits of modern contraceptives outweigh negative effects and nearly two-third $(65.2 \%)$ were interested to know more (learn more) on modern contraceptives. Furthermore, $42 \%$ of them that is four in every ten of respondents that were aware of modern contraceptives admitted that they could recommend use of modern contraceptives to a friend. In addition, for those who were non current users of modern contraceptives, a quarter $(25.4 \%)$ of them indicated they are intending use them in future. Despite positive attitude of towards modern contraceptives by a considerable proportion of women in a study population and this agreed with present study.

However, its use can be limited by negative attitude of husband towards modern contraceptives. The recent EDHS (2014) showed that $61 \%$ of currently married women in Egypt are using contraception. (37\%) using IUD, (28\%) using DMPA, (10\%) using pills, and (8\%) using Implanon. Small proportion use other methods (condom or safe period). ${ }^{11}$ In present study the most commonly LARHC method used was DMPA (80\%) of the sample women who use LARHC followed by implant $(20 \%)$ Mirena is not used between sample women as present study was done in family planning clinics and as a puplic sector but Mirena is a therapeutic tool for DUB, or endometrial hyperplasia more than a method of contraception and also is found mostly in privet clinics.

\section{CONCLUSION}

There is a good level of knowledge between upper Egypt women about LARHC methods.

\section{Recommendations}

\section{Related to the client}

Strict advice to clients who want to change to another method to switch to another method immediately after stopping the previous method also to take the injection on time to avoid occurrence of pregnancy.

\section{Related to service providers}

- Injectables and implants develop more accessibility after providing the advantages, but still need more efforts of counseling about their side effects especially amenorrhea.

- More counseling about hormonal methods in relation to the fertility is needed as most clients believes that hormonal methods especially injectables and implants decrease fertility.

- Side effects came as the highest percentage of discontinuation which could be decreased to some extent by good counseling and good training of service providers to supply the methods with little side effects.

- Good client counseling and training of service provider in supplying hormonal methods with little side effects is our aim.

- Good training of pharmacist not only physician and supplying them with good technique of counseling is needed.

\section{Related to family planning centers}

- Our population is in great need for implant which is named implanon to be supplied to all sectors, training of the service providers to insert and remove implanon is also needed.

- Good courses of organized training managed by well trained trainer should be arranged.

\section{Related to researchers}

- Another study is needed about the bleeding diaries and its relation to contraceptive methods in assessment of menstrual bleeding and irregularities.

- Another study is needed to differentiate between method failures and use failure in relation of counseling.

\section{Related to policy markers}

- The tradition and culture behavior which is still present in upper Egypt community regarding that not starting use contraceptive method except after having number of living males and more governmental organizations at national level is needed to eradicate this behavior.

With higher degree of education, the total contraception use increase meaning that the more educated clients receive counseling and pick up the idea about the method and its side effects better than less educated women there for more effort to eradicate illiteracy is needed by our social and governmental organization.

\section{Funding: No funding sources}


Conflict of interest: None declared

Ethical approval: The study was approved by the Institutional Ethics Committee

\section{REFERENCES}

1. Bulmer M, Warwick DP, eds. Social research in developing countries: Surveys and censuses in the Third World. Psychology Press; 1993.

2. Vandamme E. Concepts and challenges in the use of knowledge-attitude-practice surveys: Literature review. Department of Animal Health. Inst Trop Med. 2009;1:1-7.

3. World Population Prospects, Int, 2006 revision: Highlights. United Nations, New York, 2007.

4. Adinma B. An overview of the global policy consensus on women's sexual and reproductive rights: The Nigerian perspective. Trop J Obstet Gynaecol. 2002;19(1):9-12.

5. Obisesan KA, Adeyemo AA, Fakokunde BO. Awareness and use of family planning methods among married women in Ibadan, Nigeria. East African Med J. 1998;75(3):135-8.

6. Chichakli LO, Atrash HK, Musani AS, Johnson JT, Mahaini R, Arnaoute S. Family planning services and programmes in countries of the Eastern Mediterranean Region.

7. American College of Obstetricians and Gynecologists. Long-acting reversible contraception working group ACOG committee opinion 450: increasing use of contraceptive implants and intrauterine devices to reduce unintended pregnancy. Obstet Gynecol. 2009; 114:1434-8.

8. Glasier A. Should healthcare professionals be advocating long-acting reversible contraception? Women's Health. 2009;5:1-4.

9. National Institute of Health and Care Excellence (NICE) Long-acting reversible contraception (update) Issued: NICE clinical guideline, 30 September 2014. Available at: www.guidance.nice.org.uk/cg30.

10. Asnake M, Walie L, Melkamu Y. Improving the range of contraceptive choices in rural Ethiopia. Ethiop J Health Dev. 2006;20(2):74-8.

11. El-Zanaty F, Ann Way. Egypt Demo-graphic and Health Survey 2008. Cairo, Egypt: Ministry of Health, Available at: http://www.measuredhs.com, 2009.

Cite this article as: Mitwaly AA, Abbas AM, Mohammed AF, Ismail AM, Shaamash AH, Youssef AEDA. Knowledge, attitude and practice of long acting reversible hormonal contraception (LARHC) among women in urban upper Egypt. Int J Reprod Contracept Obstet Gynecol 2019;8:1373-9. 